\title{
TEACHING L2 LITERACY IN EARLY FORMAL CONTEXTS: A MACEDONIAN EXAMPLE
}

\begin{abstract}
Summary
There has been a growing tendency in many countries to lower the starting age of exposure to English language instruction in schools. Following suit, in 2007, English as a foreign language was introduced as a compulsory school subject from first grade in the national school curriculum of the Republic of Macedonia. This reform has received mixed reactions among key stakeholders in the process, mainly among parents and teachers, where it was perceived as an abrupt, yet, presumably positive move. Nowadays, the situation has not changed much and the relevant English teachers would still benefit from adequate training and resources. One of the stumbling stones in the process of teaching English to young learners has been the establishment of the reading and writing skills in English as a foreign language, which is the topic of the current paper. The purpose of the paper is threefold. First, it offers analysis of the perplexing situation with early formal English classes in Macedonia; second, it reviews key research studies on the context and methodology of early L2 literacy; and third, it outlines a successful example of the introduction of structured, yet adjusted, phonics in an early EFL classroom, with L2 learners having the Cyrillic script as their L1 script.
\end{abstract}

Keywords: English as a foreign language, formal settings, phonics, early biliteracy.

\section{Introduction}

There is an overwhelming presumption concerning the benefits of starting young with second language acquisition (L2A). Such consensus is grounded in theoretical assumptions about the existence of a biological critical period for language learning (Lenneberg 1967) or the existence of non-biological socio-psychological variables serving at the advantage of young learners (Moyer 1999). These theoretical arguments have often

*analazarovanikovska@gmail.com 
been supported by empirical data highlighting the ease and success of acquiring foreign languages at an early age (Johnson and Newport 1989; Thompson 1991).

Language policy makers across Europe have picked up on the scientific findings about the age factor(s) in L2A by encouraging exposure to multiple languages from an early age, both in formal and in informal contexts. Many countries and regions have lowered the starting age for compulsory language learning in the past 15 years and some even offer it in pre-school institutions: the German speaking community in Belgium, for instance, provides foreign language learning for children as young as three (Eurydice 2012; Nikolov and Curtain 2000).

Such sociolinguistic tendencies have led to the considerable growth in English language textbooks (EFL textbooks) aimed at (very) young learners. Rightly, the methodological focus in these textbooks, as well as in the classrooms, seems to have been on the development of L2 aural-oral skills with the young learners. The development of L2 literacy, at least in the Republic of Macedonia, has been left undiscussed and unguided. However, due to the fact that many children are exposed to English even in pre-school years, either formally or informally, through constant feed of English media, they reach the first grade equipped with a substantial development in L2 comprehension, and in many cases L2 oral production. Hence, they are ready and motivated to embrace L2 literacy in order to grow their knowledge of L2 English. Therefore, the issue of possible biliteracy development surfaces and practitioners struggle to grapple with it, both conceptually and methodologically.

The current paper attempts to shed light on this issue experimenting with the use of synthetic phonics with L2 children whose L1 has a Cyrillic script. The paper is organised as follows. In the second section an overview is presented of the situation with the introduction of compulsory English classes for young children in R. Macedonia in order to emphasise the need for further research. The third section focuses on the segment of L1 and L2 literacy in early formal schooling in Macedonia. In the fourth section, the i.e. reading wars are explained, elaborating on the phonics approach. In the fifth section, the notion of dual literacy is discussed and key previous research studies are presented. The sixth section presents the suc- 
cessful case study of the introduction and adaptation of synthetic phonics in a formal setting in R. Macedonia, while the seventh section concludes the findings and draws several recommendations.

\section{The status of the early English language in R. Macedonia}

Generally speaking, the English language is widely spoken in the Republic of Macedonia, especially among the younger and the middleaged population. In the formal school system, and prior to 2007, English had been a compulsory school subject starting from the fifth, i.e. fourth grade and continued as such in each grade throughout graduation from high school. Despite the rather late formal start with the English language, many youngsters attended private English classes before sixth grade, especially in urban regions, and as many were exposed to English through the media. Interestingly, numerous state schools have had the practice of establishing experimental classes, where another foreign language (usually German or French) is introduced only in one class of a particular grade level, as early as from grade 1 and often supported by diplomatic or cultural institutions representing a certain foreign country in R. Macedonia.

Nevertheless, following the practice from other European countries, it was in 2007 that English was introduced as a compulsory language in the formal school curriculum in the first grade in the Republic of Macedonia, with children aged 5-6. The curriculum presupposes that the number of weekly English classes gradually increases, from one class a week in the first grade, to two in the second and three weekly classes from the fourth to the ninth grade, when students are expected to exit primary school with an A2 CEFR level of English proficiency. Again, and especially in the cities, another European language was concurrently being taught from the first grade, albeit with less weekly classes in the lower grades in comparison to the English language.

The English teachers in the state schools (and teachers of other foreign languages, for that matter) were not given much time and training in order to equip them with the necessary knowledge and tools for the requirement to teach young learners. Representatives of relevant educational institutions, with the help of a foreign expert in the field, prepared 
a Teacher's Handbook for English in the first grade with the aim to assist English teachers in the transition and with the assumption that a coursebook is not needed for students in the first grade. However, the outcome falls short of reaching its goal for the following main reasons: a) more professional development needs to be organised to prepare the existing English teachers for a young learners audience; b) additional didactic materials are needed in order to successfully organise language classes with young children (e.g. an activity book, flashcards, posters, storybooks, multi-media units, realia, if not a coursebook); c) care should be taken to carefully select the English course materials for the subsequent grades in order to ensure gradual and adequate continuation of the curriculum. As a result, reports from teachers seem to indicate that some of them are making endeavours to implement the Handbook, while others have decided to use a coursebook and an activity book in English from a selection of wellknown foreign publishers as early as grade one. Subsequently, in grades 2 and 3 rather non-demanding, age-appropriate, yet not necessarily curriculum appropriate, coursebooks by renowned foreign publishers are in use, while in grade 4 there is a sudden change in style and level, which many students find difficult to follow.

It may be worth to mention that numerous kindergarten-goers also opt to learn English twice a week, on extra-curricular basis. In light of the moto "the sooner the better" such practice would be deemed beneficial; however, in reality it often leads to overlap in the use of specific coursebooks and more certainly of the curricula between the English covered in kindergarten and that covered in grades 1-3. Such reality results in demotivation, especially among the more proficient young learners of English, but also it gives rise to the opportunity to use the gradual and careful introduction of L2 literacy skills as a unifying factor between what we might term "false and real" young learners beginners.

\section{The introduction of L1 and L2 literacy in R. Macedonia}

Although one would not immediately think of literacy as a skill when the subject matter is young learners of a foreign language, for reasons outlined above, it may be worth considering the need to begin with teaching 
reading and writing in English earlier than it is planned at the moment.

In order to consider the teaching of English literacy, we shall outline first the introduction of L1 (Macedonian) literacy. According to the national curriculum for grade 1, teachers begin with raising children's phonemic awareness in their mother tongue, then in grade 2 they start learning the $\mathrm{Cy}$ rillic/Macedonian alphabet, first the printed letters, then the cursive forms, while in grade 3 the Latin alphabet is taught, although it is not an official script of the Macedonian language. The Macedonian language has shallow orthography. Hence, teaching how to read and write seems to be a rather straightforward process as there is a direct correspondence between the letters and the sounds; all children need to learn are the shapes of the letters.

Based on the national curriculum, the rudiments of L2 (English) literacy are planned in grade 2 , with the recommendation that visual recognition of familiar vocabulary should be encouraged. Then, in grade 3 , the student is expected to learn the English alphabet as well as how to read new words and write familiar ones. Suggested activities include: reading aloud, joining words and short sentences with pictures, filling in missing letters, arranging words with scrambled letters and spelling exercises. There are no bottom-up recommendations about the actual process of reading. In the classroom, teachers do try to follow the given guidance, however, teaching L2 literacy usually amounts to singing the alphabet song a few times, writing the alphabet letters (often with Cyrillic transcripts) followed by numerous dictations, mostly too soon before the letters and their spelling had been really mastered. Such dynamic confuses and frustrates especially the young learners who had not had private English classes prior to starting compulsory schooling.

At the same time, the process of literacy starts informally much earlier for most children. On the one hand, increasing number of kindergarten children know some, if not all the letters of the Macedonian alphabet before starting formal schooling. In addition, many children these days seem to be computer-literate, which makes them familiar at least with some of the letters of the English alphabet. Such a reality also facilitates the introduction of the idea of earlier L2 literacy in the formal schooling system.

In sum, early L2 literacy from grade 1 may be beneficial as it may serve as common ground for children with diverse previous knowledge of the English language: it will be the needed challenge to those who were 
fortunate enough to be exposed to English before grade 1 and to those with a greater aptitude in language learning, whereas at the same time, it will also give the needed confidence to children who enter first grade with knowledge of only a handful of English words. In L2 literacy, they would all be quite novice in grade 1, but not necessarily in later grades. Not only does it seem that L2 English literacy is introduced too late in the system, but teachers seem to be expecting positive results too quickly and literacy teaching is possibly carried out in a less efficient way by using the wholelanguage approach, which will be discussed in the next section.

\section{Approaches to $\mathbf{L} 2$ reading and writing in English}

Reading and writing are complex cognitive processes which need to be learnt and they represent an important educational milestone both for children and for parents. There are several formal approaches to teaching L1 literacy, especially reading, and some of them are known under different names. Nevertheless, they can mainly be divided into two categories: the Skillbased approach (a.k.a. bottom-up approach, phonics) and the Comprehension approach (a.k.a. top-down approach, "look and say", whole word or whole language approach) (Krashen 2002). Some authors make finer distinctions among the approaches, for example, Cameron (2010) lists emergent literacy and the language experience approach in addition to the whole word and phonics teaching to reading. Regardless of the terminology, the central distinction remains between a more holistic and a more structural/analytical approach to reading. The two broad approaches to reading have been taking turns in their dominance over the national educational policies in the UK and the USA over the last 50 years.

Based on the Skill-based approach, the child learns to read by first learning to read out loud, by learning sound-spelling correspondences (Just and Carpenter 1987). This is done through explicit instruction, practice, and correction. This knowledge is first applied to words. Ultimately, the child uses this ability to read larger texts, as the knowledge of sound-spelling correspondences becomes automatic. According to this view, reading of interesting texts is helpful only to the extent that it helps children "practice their skills". Understanding that there is a direct relationship between letters and sounds enables a 
reader to retrieve the pronunciation of an unknown word and associate it with a spoken word. It is also the foundation of learning to spell.

The supporters of the Comprehension approach, on the other hand, claim that we learn to read by understanding messages on the page; in a logographic manner, students "look at the whole word" and say it, without decoding it first (Goodman 1982; Smith 1994). Reading pedagogy, according to the Comprehension approach, focuses on providing students with interesting, comprehensible texts, and the job of the teacher is to help children read these texts, that is, help make them comprehensible. The direct teaching of "skills" is helpful only when it makes texts more comprehensible.

In the UK, and following the Rose report (2006) as well as other independent studies, it has been concluded that phonics instruction, in particular systematic phonics, was found to have a statistically significant positive effect on reading accuracy (in comparison to whole-word approaches), especially when used within a rich, meaningful literacy curriculum (Lazarova-Nikovska 2014; Torgerson, Brooks, and Hall 2006). Outside the UK, particularly in India and in the African countries, where English is not the first language, synthetic phonics programmes have achieved remarkable results (Gross 2010).

Phonics is a system which involves teaching learners how to connect the letters of words with the sounds they represent, rather than reading and comprehending whole words at once (Lloyd 2000). Thus, the beginning reader must learn the connections between the approximately 44 sounds of spoken English (the phonemes), and the 26 letters of the alphabet. Phonemic awareness, the understanding that a word is made up of a series of discrete sounds, is an essential pre-requisite for successful phonics instruction (Adams 1990). There are two types of phonics instruction, synthetic and analytic, although the difference is of little relevance for the purposes of the current paper. Regardless of the type used, its early introduction in the literacy instruction has been advocated by many authors, with the explanation that it leads to better reading: better accuracy of word recognition, decoding, spelling, and oral and silent reading comprehension (Chall 1996).

Reading and writing are interrelated and complementary processes (Pinnell et al. 1994). When discussing early L2 literacy, more emphasis is usually placed on the reading aspect of it, while the writing part is expected to be mastered in parallel and simply with plenty of writing practice. With regard to 
the earliest stages, recommendations can often be found even about the correct grip of a pencil. Moreover, research and methodologies on L2 writing seem to focus more on other and later aspects of the writing skill, e.g. distinguishing between product and process approaches to writing (Cumming 2001).

Choosing the right literacy method is only one aspect of the dilemma with early literacy. Another one is the time when L2 literacy should be introduced. In other words, should it follow the mastery of L1 literacy, can they run simultaneously, or is it safe or even beneficial if L2 literacy precedes the introduction of L1 literacy? To this debate, we turn in the next section.

\section{The prospect of dual literacy}

Although there is abundance of research generally on bilingualism, there are fewer studies which tackle the issue of the development of literacy in two or more languages. Among those, the majority deal with the transfer of language skills between languages, i.e. with the effect of L1 literacy on the development of L2 literacy and report positive effects, in the sense that being literate on one's mother tongue helps the learner to master the literacy in the foreign language (Cummins 2005; Gudschinsky 1977; Ramírez 2000). There is even less research on parallel development of two literacies (e.g. Berens et al. 2013; Escamilla et al. 2014; Giambo and Szecsi 2015) or on cases where L2 literacy precedes L1 literacy and is showing to have positive effects on the L1 literacy mastery of the students (e.g. Al Dohon 2014; Hussein et al. 2014). In the study by Ahmadi, Khoii, and Taghadosian (2015), a group of bilingual children, who were taught Persian-English literacies simultaneously, developed their literacy skills in the L1, e.g. reading fluently, accurately and dictation, equally well in the short run with the group of monolingual children who were taught only the L1 Persian literacy. Moreover, the long term results of this study showed an advantage of the biliterate group in terms of reading fluency in the L1. All the studies mentioned above document the advantages of biliterates in L1 reading mastery, despite the widespread concern expressed by practitioners about the possible delay and damage done to the mastery of the L1 literacy skills.

Considering more general bilingual development, there is no scientific evidence to support confusion between languages, or presumed 
language difficulties, delay, or disorders often attributed by sceptics to early bilinguals (Byers-Heinlein and Lew-Williams 2013). There is initial code-switching, which is often rule-governed and which usually reduces or disappears with the increase of vocabulary development in each of the languages. Hence, we can assume a similar scenario for early biliteracy development, i.e. that any initial mixing of the two scripts will only be temporary.

In the Republic of Macedonia, the prevailing approach to L2 literacy used in state schools and many private language schools is the whole-word approach, while little is known about phonics. Phonics is practiced in a few private educational institutions, confirming its positive effects (Stojanovska-Simonovski 2013; Temelkovska 2017). Considering the attested benefits of early phonics, together with the need to introduce literacy as early as the ages of 5 and 6 , as well as the fact that no detrimental effects have been reported for the concurrent learning of both literacies, we have decided to implement structured synthetic phonics as part of the regular English language classes for young children in the private language centre Elokventa in R. Macedonia. In the centre, young learners attend English classes twice a week, where each class lasts 60 minutes, with the exception of the youngest learners (ages 5-6) whose classes last 45 minutes. They use EFL coursebooks from a renowned publisher, where a phonics section is included in each unit. However, based on the experience in the classroom, it was decided that a separate, more structured and differently sequenced path to mastering L2 literacy should be developed for the learners. To that modified programme, we turn in the next section.

\section{A Macedonian example on adapted L2 literacy methodology}

There are numerous programmes which can be used to teach phonics, such as the Letters and Sounds (2015), The Butterfly Book (Tyk 2007), Jolly Phonics (1987-2018), among others. We have decided to rely on the Jolly Phonics programme and resources as our main framework, although we were open to the possibility of adjusting it to suit the needs and the circumstances of our learners. There are three aspects of our experience that are worth presenting in the current paper: a) the stages, b) the 
method, and c) the techniques and activities used to teach English literacy using phonics.

Stages

There are three key stages we follow:

- Stage 1 (ages 5-6)

At the beginning of this stage, the focus is on raising phonemic awareness, the use of nursery rhymes, and the development of the fine motor skills. This foundation lasts about two months, when we begin with the structured introduction of phonics, by practicing the recognition of all the single letters of the English alphabet using the sound-form mapping typical of phonics. After the introduction of the first three letters, attempts at blending are endeavoured, using the few real words that the young learners may be familiar with at that stage, but also relying substantially on the use of short pseudowords, which have proven to be beneficial, especially in this earliest stage (Cardenas 2009; Temelkovska 2017).

- Stage 2 (ages 7-8)

In the second stage, all the previously learnt single letters are revised. Then, what follows is structured introduction of digraphs and diphthongs. Mostly to attain compliance with the English curriculum in the state schools, we have decided to introduce children to the names of the alphabet letters and standard spelling at this stage too. Finally, mainly due to the exposure to more materials and texts in the English language, we have also identified the need for the introduction of the spelling of sight words, which these young learners most frequently encounter.

- Stage 3 (ages 8-9)

As far as structured phonics is concerned, the third stage is predominantly reinforcement of the previous two stages. By this stage, the young learners are quite confident readers and are comfortable with the spelling of the most frequent regular and irregular 
words and shorter sentences. Hence, at this stage we continue with the practice of sight words, but we also gradually turn our attention from the technicalities of reading to reading for comprehension.

Each of these stages lasts around eight months.

\section{Method}

At the end of each class, there is an allocated time, 5-10 minutes, exclusively for structured phonics instruction. Lower case letters are introduced from the start (with a joining tail) together with the printed form of the letter. Blending is attempted after the introduction of the first three letters, and regularly thereafter with the introduction of each new set of three letters, as well as with combinations of all previously learnt letters. Both familiar and pseudowords are used for practicing phonics. There is a regular revision of previously introduced letters as well as motivational homework in stages 2 and 3, where, for example, students are required to find words with the letter $/ \mathrm{n} /$ in initial, medial and final position of the word.

What is further interesting is the modified sequence of letters and sight words that are used in the particular language centre. Namely, for the initial sequence of single letters, the Jolly Phonics programme uses the letters S A T I P M. We have decided, however, to change that sequence and begin phonics instruction with the letter sequence A O M T E K. This was decided due to the similarities between the Latin and the Cyrillic alphabet with the latter set of letters, at least in their printed form. The letters from the set are one of the first ones children learn even in their mother tongue and we reckoned that they would serve to encourage the young learners that English spelling is not very difficult and different from Macedonian spelling. Similar motivational philosophy is used when teachers are encouraged to introduce international words and cognates in the first classes, both with children and with adults. With respect to the general letter sequence, there were also some adjustments made. Namely, the Jolly Phonics programme used first a few single letters, then combinations of single letters and diphthongs, whereas in Elokventa we decided that all single letters should be introduced first, for simplicity reasons. Finally, in the 
stages when the sight words are introduced, it was decided that the Dolch list should be followed as a framework. However, necessary alterations needed to be made with these lists too, as the initial Dolch lists include words found in authentic English children's books, e.g. said, did, which are suitable for native English speakers, but not necessarily for young L2 learners. Therefore, in Elokventa, the initial lists were reworked to also include words found in the first EFL textbooks, e.g. can, go, blue and some Dolch words aimed at natives were excluded.

\section{Techniques}

As the aim of the current paper is not to present in details the classroom activities during phonics time, we shall briefly mention that a myriad of techniques and activities are used in order to liven the focused time spent on phonics during our classes. For instance, we use multisensory approaches such as air and sand writing, play dough letter creations, letter magnets, shoe lace braiding, among other. Our young learners love to explore the varied realia found around the classroom: wipe out books, alphabet toys, flashcards, letter magnets, foam letters, puzzles, etc. We certainly use the wonderful Jolly Phonics handouts for letter tracing and practicing, but we also add to them relevant words which we know that are familiar to our learners. Essential component are the various TPR activities and games, such as letter formation using the arms and the body, looking for letters in the classroom, or in books, all of which appeal to the curious and kinaesthetic nature of young learners.

The main goal of the current paper was to advocate the use of phonics in EFL settings and to encourage the possibility of adjusting an already established phonics programme to suit the needs of a particular educational context (e.g. LF learners with Cyrillic alphabet). In the case of the Macedonian example presented above, the focus was on implementing the phonics methodology among the Macedonian young learners, i.e. deciding on the stages, materials and methods to be used during the instruction period. The outcome of the phonics implementation and the literacy results have not been systematically measured and assessed, at least with the cur- 
rent group of students. This is planned in Elokventa as a continuous project, maintaining our interest in the use of phonics in the EFL classroom. Nevertheless, we would like to communicate that, based on the ongoing observation of the students' mastery of the planned literacy stages, they showed the desirable progress, had no issues with the structured aspect of the literacy programme and found the techniques used particularly engaging and motivating.

\section{Conclusion}

With the increased personal mobility, migration and the refugee crisis, there will be a growing number of bilingual and multilingual children on the global scene. Even within a single country, the early exposure to English technology and media is also contributing to the rise of bilingual children. This will urge researchers and practitioners to reconsider and update the governing language policies. One of the aspects to be monitored should be the learning of literacy in a foreign language, as reading and writing are prerequisites for one's economic and social survival and success.

In the light of insufficient data on the process and outcome of dual literacy, the goal of the current paper is to report on a positive case study using a modified phonics instruction with young L1 Macedonian learners of L2 English. What this experience has taught us is that structured early L2 literacy is possible, advisable, it can be taught in a cognitively nondemanding way, but rather creatively and playfully and it can be carried out simultaneously with or even preceding L1 literacy. Moreover, it does not seem to interfere with the development of L1 literacy for the majority of the children. In cases where letter confusion would arise, it remains only anecdotal and short-lived. We have thus far focused on the initial stages of L2 literacy introduction and we shall certainly continue to further modify the model based on experience. However, it has generally proven to be a successful one, which allows us to concentrate in the future on establishing motivational and effective methods to expand the reading and writing skills of L2 learners beyond the initial mastery of literacy as a language component. 


\section{References}

Adams, Marilyn J. 1990. Beginning to Read: Thinking and Learning About Print. Cambridge, MA: MIT Press.

Ahmadi, Newsha, Roya Khoii, and Hediyeh Taghadosian. 2015. "Simultaneous teaching of L1 and L2 literacy to young Iranian learners: A threat or a treat?". LICEJ Special issue 4 (1): 2111-2119.

Al-Dohon, Hatem. 2014. "The Effect of Second-Language Learning on Elementary EFL Learners' Literacy Skills.” International Journal of Education and Research 2 (6): 350-360.

Berens, Melody S., Ioulia Kovelman, and Laura-Ann Petitto. 2013. "Should Bilingual Children Learn Reading in Two Languages at the Same Time or in Sequence?”. Bilingual Research Journal 36 (1): 35-60.

Byers-Heinlein, Krista, and Casey Lew-Williams. 2013. "Bilingualism in the Early Years: What the Science Says." LEARNing Landscapes 7 (1): 95-111.

Cameron, Lynne. 2010. Teaching Languages to Young Learners. Cambridge University Press.

Cardenas, Jessica Marie. 2009. "Phonics Instruction using Pseudowords for Success in Phonetic Decoding." EdD diss., Florida International University.

Chall, Jeanne S. 1996. Learning to read: The great debate, 3rd ed. New York: McGraw-Hill.

Cumming, Alister. 2001. "Learning to write in a second language: Two decades of research." IJES 1 (2): 1-23.

Cummins, Jim. 2005. “A proposal for action: Strategies for recognizing heritage language competence as a learning resource within the mainstream classroom." The Modern Language Journal 89 (4): 585-592. Escamilla, Kathy, Susan Hopewell, Sandra Butvilofsky, Wendy Sparrow, Lucinda Soltero-González, Olivia Ruiz-Figueroa, and Manuel Escamilla. 2013. Biliteracy from the Start: Literacy Squared in Action. Caslon: Caslon Publishing.

Eurydice. 2012. Key Data on Teaching Languages at School in Europe. European-Commission. Accessed March 10, 2017. http:/eacea.ec.europa. eu/education/eurydice/documents/key_data_series/143EN_HI.pdf. 
Giambo, Debra A., and Tunde Szecsi. 2015. "Promoting and maintaining bilingualism and biliteracy: Cognitive and biliteracy benefits \& strategies for monolingual teachers." The Open Communication Journal 9 (Suppl. 1: M8): 56-60.

Goodman, K. 1982. Language, Literacy and Learning. London: Routledge Kagan Paul.

Gross, Miriam. 2010. So Why Can't They Read? Surey: Centre for Policy Studies.

Gudschinsky, Sarah. 1977 "Mother tongue literacy and second language learning." In Bilingualism in Early Childhood, edited by William Francis Mackey and Theodore Andersson, 250-258. Rowley, MA: Newbury House Publishers.

Hussein, Abdelaziz M. 2014. "The effect of learning English (L2) on learning Arabic literacy (L1) in the primary school." International Education Studies 7 (3): 88-98.

Johnson, Jacqueline S., and Elissa L. Newport. 1989. "Critical period effects in language learning: The influence of maturational state on the acquisition of English as a second language." Cognitive Psychology 21 (1): 60-99.

Jolly Phonics. 1987-2018. Jolly Learning Educational Publisher. http://jollylearning.co.uk/overview-about-jolly-phonics/

Just, Marcel Adam, and Patricia A. Carpenter (eds.). 1987. The Psychology of Reading and Language Comprehension. Newton MA: Allyn and Bacon.

Krashen, Stephen. 2002. "Defending whole language: The limits of phonics instruction and the efficacy of whole language instruction." Reading Improvement 39 (1): 32-42.

Lazarova-Nikovska, Ana. 2014. "Introducing literacy in the UK: A case for phonics." Journal of Social and Human Sciences 1 (1): 31-43.

Lenneberg, Eric H. 1967. Biological Foundations of Language. New York: Wiley. Letters and Sounds. 2015. Free Resources for letters and sounds phonics. http://www.letters-and-sounds.com.

Lloyd, Sue. 2000. The Phonics Handbook. UK: Jolly Learning Ltd.

Moyer, Alene. 1999. "Ultimate attainment in L2 phonology: The critical factors of age, motivation, and instruction." Studies in Second Language Acquisition 21 (1): 81-108. 
Nikolov, Marianne, and Helena Curtain (eds.). 2000. An Early Start: Young Learners and Modern Languages in Europe and Beyond. Council of Europe.

Pinnell, Gay Su, Carol A. Lyons, Diane E. Deford, Anthony S. Bryk, and Michael Selzer. 1994. "Comparing instructional models for the literacy education of high-risk first graders." Reading Research Quarterly 29 (1): 8-39.

Ramírez, J. David. 2000. "Bilingualism and literacy: problem or opportunity? A synthesis of reading research on bilingual students." In A Research Symposium on High Standards in Reading for Students from Diverse Language Groups: Research, Practice \& Policy, Proceedings, 9-41. Washington, DC: U.S. Department of Education.

Rose, Jim. 2006. Independent review of the teaching of early reading. Ref. 0201-2-006DOC-EN. Nottingham: DfES.

Simonovska-Stojanovski, Emilija. 2013. "Developing reading skill through phonics instruction in young learners of English." In Proceedings from the International Conference in Applied Linguistics: Practice in Language, Language in Practice, 166-175. Skopje: FON University.

Smith, Frank. 1994. Understanding Reading, 5th ed. Hillsdale, NJ: Erlbaum. Temelkovska, Stefanija. 2017. Pseudowords phonics instruction for success in literacy development with young learners in Macedonia. Unpublished MA thesis, FON University, Skopje, R. Macedonia.

Thompson, Irene. 1991. "Foreign accents revisited: The English pronunciation of Russian immigrants." Language Learning 41 (2): 177-204.

Torgerson, Carole J., Greg Brooks, and Jill Hall. 2006. A Systematic Review of the Research Literature on the Use of Phonics in the Teaching of Reading and Spelling. Brief No. RR711. Nottingham: DfES.

Tyk, Irina. 2007. The Butterfly Book: A Reading and Writing Course. London: Civitas. 


\title{
Ana Lazarova-Nikovska
}

\section{RAZVOJ PISMENOSTI NA STRANOM JEZIKU U FORMALNOM OBRAZOVANJU NA RANOM UZRASTU: PRIMER MAKEDONIJE}

\begin{abstract}
Sažetak
U mnogim zemljama je sve prisutnija tendencija da se engleski jezik uvede u nastavu od ranog uzrasta. U skladu sa tim, 2007. godine engleski kao strani jezik postao je obavezan predmet od prvog razreda formalnog obrazovanja u Republici Makedoniji. Ova mera je naišla na različite reakcije uključenih u proces obrazovanja, a posebno roditelja i nastavnika među kojima je prihvaćena kao nagla iako pozitivna promena. Okolnosti se nisu značajno promenile do današnjeg dana, te bi svakako bilo korisno pružiti adekvatnu obuku nastavnicima engleskog jezika koji rade sa decom ranog uzrasta, ali i obezbediti odgovarajući nastavni materijal. Kamen spoticanja u nastavi engleskog za decu ranog uzrasta odnosi se na uvođenje čitanja i pisanja na engleskom kao stranom jeziku, što je i tema ovog rada. Naime, prvo razmatramo složene okolnosti koje su pratile uvođenje engleskog jezika u formalno obrazovanje Makedonije na ranom uzrastu; potom prikazujemo ključne studije koje se bave kontekstom i metodologijom za uvođenje opismenjavanja na stranom jeziku u ranom uzrastu; konačno, predstavljamo primer dobre prakse u okviru koje se primenjuje strukturisana i prilagođena metoda fonacije u ranom učenju engleskog kao stranog jezika kod učenika kojima je ćirilica primarno pismo.
\end{abstract}

Ključne reči: engleski kao strani jezik, formalno obrazovanje, fonacija, dvojezično opismenjavanje, rano učenje jezika. 